\title{
Formation and emission of brominated dioxins and furans during secondary aluminum smelting processes
}

\author{
Mei Wang, Guorui Liu*, Xiaoxu Jiang, Sumei Li, Wenbin Liu, Minghui Zheng \\ State Key Laboratory of Environmental Chemistry and Ecotoxicology, Research Center for Eco-Environmental Sciences, Chinese Academy of Sciences, P.O. Box
} 2871, Beijing 100085, China

\section{H I G H L I G H T S}

- PBDD/F emissions from different secondary aluminum smelters were investigated.

- The raw material composition significantly influenced PBDD/F emissions.

- The feeding-fusion stage was the main stage in which PBDD/Fs were emitted.

- Effective metal scrap pretreatments can significantly decrease PBDD/F emissions.

- The more-brominated PBDD/F congeners were dominant.

\section{A R T I C L E I N F O}

\section{Article history:}

Received 28 July 2015

Received in revised form

20 November 2015

Accepted 26 November 2015

Available online 18 December 2015

Handling Editor: Dr. Gang Yu

\section{Keywords:}

PBDD/Fs

Secondary aluminum smelters

Stack gas

Raw materials

Persistent organic pollutants

\begin{abstract}
A B S T R A C T
Secondary aluminum smelting (SAl) processes have previously been found to be important sources of polybrominated dibenzo-p-dioxins and dibenzofurans ( $\mathrm{PBDD} / \mathrm{Fs}$ ). It is crucial that the key factors that influence the formation and emission of PBDD/Fs are identified to allow techniques for decreasing PBDD/ F emissions during SAl processes to be developed. In this study, stack gas samples were collected from four typical secondary aluminum smelters that used different raw materials, and the samples were analyzed to allow differences between PBDD/F emissions from different SAl plants to be assessed. The composition of the raw materials was found to be one of the key factors influencing the amounts of $\mathrm{PBDD} / \mathrm{Fs}$ emitted. The PBDD/F emission factors (per tonne of aluminum produced) for the plants using $100 \%$ (Plant1), 80\% (Plant2), and 50\% (Plant3) dirty aluminum scrap in the raw material feed were 180 , 86 , and $14 \mu \mathrm{g} \mathrm{t}^{-1}$, respectively. The amounts of PBDD/Fs emitted at different stages of the smelting process (feeding-fusion, refining, and casting) were compared, and the feeding-fusion stage was found to be the main stage in which PBDD/Fs were formed and emitted. Effective aluminum scrap pretreatments could significantly decrease PBDD/F emissions. Much higher polybrominated dibenzofuran concentrations than polybrominated dibenzo-p-dioxin concentrations were found throughout the SAl process. The more-brominated congeners (including octabromodibenzo- $p$-dioxin, octabromodibenzofuran, heptabromodibenzo-p-dioxins, and heptabromodibenzofurans) were the dominant contributors to the total PBDD/F concentrations. The results could help in the development of techniques and strategies for controlling PBDD/F emissions during metallurgical processes.
\end{abstract}

() 2015 Elsevier Ltd. All rights reserved.

\section{Introduction}

Secondary aluminum smelters primarily recover aluminum from new and used scrap and dross containing aluminum (Ba et al., 2009). Scrap metal and metal waste may also contain organic

\footnotetext{
* Corresponding author.

E-mail address: grliu@rcees.ac.cn (G. Liu).
}

materials, such as paints, plastics, and solvents (Kevorkjjan, 2010). Secondary aluminum smelting ( $\mathrm{SAl}$ ) may lead to the unintentional formation of persistent organic pollutants (POPs), including polychlorinated dibenzo-p-dioxins and dibenzofurans (PCDD/Fs), polybrominated dibenzo-p-dioxins and polybrominated dibenz ofurans (PBDDs and PBDFs, together called PBDD/Fs), and dioxinlike compounds (such as polychlorinated biphenyls (PCBs) and polychlorinated naphthalenes (PCNs)), because of the incomplete combustion of impurities in the raw materials (Hu et al., 2013a). 
Unintentionally produced POPs can form through reactions between inorganic or organically bound halogen atoms and carbon from organic material in scrap metal or other materials (such as partially burnt fuels or the reductants) (Weber and Kuch, 2003; Altarawneh et al., 2009; Ortuño et al., 2014). This process can be catalyzed by aluminum, copper, and other metals (Weber et al., 2001; Ryu et al., 2003; Fujimori et al., 2009, 2013).

The formation and emission of PCDD/Fs, PCBs, and PCNs during SAl processes have previously been studied in detail, and SAl has been found to be an important source of these chlorinated compounds (Chen et al., 2004; Lee et al., 2005; Li et al., 2007; Ba et al., 2010; Hu et al., 2014; Jiang et al., 2015). Ba et al. (Ba et al., 2009, 2010) measured PCDD/F, dioxin-like PCB, and PCN emissions from Chinese secondary aluminum metallurgical plants and estimated that the total amounts of PCDD/Fs, dioxin-like PCBs, and PCNs emitted to the atmosphere in 2007 were $7.3,0.53$, and $0.39 \mathrm{~g}$ toxic equivalents (TEQ), respectively. Grochowalski et al. (Grochowalski et al., 2007) found much higher concentrations of PCDD/Fs (0.030-0.58 ng International TEQ Nm $\left.{ }^{-3}\right)$, PCBs (0.0080-0.054 ng World Health Organization TEQ $\mathrm{Nm}^{-3}$ ), and hexachlorobenzene $\left(11-23 \mathrm{ng} \mathrm{Nm}^{-3}\right)$ in flue gases at a SAl in Poland than in flue gases produced during other industrial thermal processes. Daily inhaled doses of PCDD/Fs, dioxin-like PCBs, and PCNs in SAl plants that exceed the tolerable daily intake recommended by the World Health Organization have been found (Hu et al., 2013a). Lee et al. (Lee et al., 2009) measured PCDD/F concentrations in serum from 134 workers in electric arc furnace, secondary copper smelting, and SAl plants. The highest PCDD/F concentrations were found in the serum samples from the SAl workers. The studies described above showed that SAl plants are important sources of unintentionally produced chlorinated POPs.

Intensive studies of PCDD/F, PCB, and PCN emissions during SAl processes have been performed (Chen et al., 2004; Lee et al., 2005; Li et al., 2007; Ba et al., 2010; Hu et al., 2014; Jiang et al., 2015), but emissions of the toxic brominated analogs of these pollutants, particularly PBDD/Fs, have been investigated in few studies. PBDD/ Fs are the brominated analogs of PCDD/Fs, so PBDD/Fs have similar physicochemical properties, toxicities, and environmental behaviors to PCDD/Fs (Behnisch et al., 2003; Birnbaum et al., 2003; Olsman et al., 2007; Samara et al., 2009). PBDD/Fs have recently been found in various environmental matrices (Haglund et al., 2007; Li et al., 2008; Chang et al., 2013; Zacs et al., 2013). It has previously been suggested that polybrominated diphenyl ethers (PBDEs) are important precursors of PBDD/Fs in industrial thermal processes (Sakai et al., 2001; Weber and Kuch, 2003; Olsman et al., 2007; Duan et al., 2011; Altarawneh and Dlugogorski, 2013; Sindiku et al., 2014). Significant amounts of PBDEs have been found in the raw materials of SAl plants. For example, Sinkkonen et al. (Sinkkonen et al., 2004) screened four raw scrap material samples from a SAl plant for persistent halogenated aromatic compounds and found PBDEs in all of the samples, at concentrations of 250-67,000 ng g $^{-1}$. The presence of bromine-containing materials and various nonferrous metals in the raw materials used in the SAl process naturally means that the formation of $\mathrm{PBDD} / \mathrm{Fs}$ during the SAl process should be considered.

Although PBDD/Fs are believed to be formed during SAl processes, few data on PBDD/F emissions from secondary aluminum metallurgical facilities have been reported. To the best of our knowledge, only one study of PBDD/Fs in stack gas samples from only one SAl plant has been published (Du et al., 2010). However, the effects of factors that could affect PBDD/F emissions (e.g., the smelting techniques used, the furnace capacity, the raw materials, and the fuel) were not thoroughly investigated in that study. More case studies are therefore needed to allow PBDD/F emissions during SAl processes to be systematically evaluated.
China is the world's largest producer and consumer of aluminum, accounting for roughly $40 \%$ of global aluminum production (Chen and Shi, 2012; Lo and Wang, 2013). Secondary aluminum production in China increased dramatically after 2000, and now accounts for roughly $22 \%$ of the total amount of aluminum produced, producing three million tonnes in 2009 (Chen and Shi, 2012; Lo and Wang, 2013). Investigating PBDD/F emissions from typical Chinese SAl plants is therefore likely be important to allow a preliminary estimate of global PBDD/F emissions from SAl plants to be made.

In this study, PBDD/F emissions from four typical SAl plants with different furnace capacities and using different raw materials were investigated. The primary objective was to estimate PBDD/F emissions from typical SAl plants in China. A further objective was to identify the factors that influence PBDD/F emissions. The results of this study will provide helpful information to develop and implement measures to control PBDD/F emissions.

\section{Materials and methods}

\subsection{Sample collection}

Secondary aluminum production in China is mostly performed using reverberatory furnaces because such furnaces have simple structures, are easy to operate, and are suitable for large-scale production (Hu et al., 2013b; Jiang et al., 2015). Scrap containing aluminum is the main raw material used in Chinese SAl plants. Fabric bag filters are widely used as air pollution control devices in Chinese SAl plants (Ba et al., 2010; Hu et al., 2013b; Jiang et al., 2015). Four typical Chinese SAl plants with reverberatory furnaces and bag filter air pollution control devices were studied. The plants, labeled Plant1, Plant2, Plant3, and Plant4, were selected because they used different mixtures of raw materials. The raw material used in Plant1 and Plant4 was 100\% dirty aluminum scrap (used and discarded material, such as appliances, aluminum foil, automobile and airplane parts, aluminum sidings, and beverage cans). The raw material used in Plant2 and Plant3 contained $80 \%$ and $50 \%$ dirty scrap, respectively. The remaining $20 \%$ of the raw material used in Plant2 was copper-clad aluminum wire. The remaining $50 \%$ of the raw material used in Plant3 was clean aluminum scrap (pre-consumer scrap material, such as waste from the drilling and machining of aluminum castings, waste from fabrication and manufacturing operations, and dross skimmed off molten aluminum during the smelting process). Additional information on the plants is given in Table S1.

A total of 15 stack gas samples from different smelting stages were collected from the four SAl plants. The samples were collected using an automatic isokinetic sampling system (Isostack Basic; TCR Tecora, Fontenay sous Bois, France) that has been used in previous studies (Liu et al., 2009, 2010). The sampling system consisted of Isostack Basic pumps, Isofrost coolers, a heated titanium probe, a filter box with a Whatman quartz microfiber thimble filter (GE Healthcare Bio-Sciences, Pittsburgh, PA, USA), and a water-cooled Amberlite XAD-2 (Supelco, Bellefonte, PA, USA) adsorbent trap. The quartz fiber filter was used to collect the particle-bound pollutants and the XAD-2 adsorbent resin was used to trap the vaporphase pollutants. ${ }^{37} \mathrm{Cl}_{4}$-labeled 2,3,7,8-tetrachlorodibenzo-p-dioxin was spiked into the resin prior to sampling to allow the sampling efficiency to be evaluated. After collection, each sample was wrapped tightly in aluminum foil and packed in a sealed polyethylene bag to prevent it becoming contaminated or material being lost.

\subsection{Analytical procedures}

Thirteen 2,3,7,8-brominated PBDD/F congeners were identified 
and quantified in this study (17 2,3,7,8-chlorinated PCDD/F congeners are generally quantified) because several ${ }^{13} \mathrm{C}_{12}$-labeled compounds that would ideally be used as internal standards are currently not commercially available. The PBDD/F congeners were identified and quantified using an isotope dilution high-resolution gas chromatography combined with high-resolution mass spectrometry method. Full details of the analytical methodology have been published previously (Wang et al., 2015). Briefly, each stack gas sample was spiked with a mixture of ${ }^{13} \mathrm{C}_{12}$-labeled $\mathrm{PBDD} / \mathrm{F}$ internal standards (EDF-5408; Cambridge Isotope Laboratories, Andover, MA, USA), then Soxhlet extracted for approximately $24 \mathrm{~h}$ with $250 \mathrm{~mL}$ of toluene. The extract was concentrated using a rotary evaporator and then subjected to a series of clean-up steps, including a multilayer silica gel column and a basic alumina column. A silica gel column impregnated with active carbon was then used to separate the PBDD/Fs from other compounds. The fraction containing PBDD/Fs was concentrated to approximately $20 \mu \mathrm{L}$ using a rotary evaporator and then under a gentle stream of $\mathrm{N}_{2}$. Then, ${ }^{13} \mathrm{C}_{12}$-labeled PBDD/F injection standards (EDF-5409; Cambridge Isotope Laboratories) were added to allow the internal standard recoveries to be calculated. The extract was then analyzed for PBDD/Fs using a Trace GC Ultra gas chromatograph coupled to a DFS mass spectrometer (Thermo Fisher Scientific, Waltham, MA, USA) with an electron impact ion source. The mass spectrometer was operated in selected ion monitoring mode with a resolution of approximately 10,000 . The $\mathrm{PBDD} / \mathrm{F}$ congeners were separated on a DB-5 MS capillary column ( $15 \mathrm{~m}$ long, $0.25 \mathrm{~mm}$ i.d., $0.1 \mu \mathrm{m}$ film thickness; Agilent Technologies, Santa Clara, CA, USA). The electron energy was $45 \mathrm{eV}$ and the source temperature was $280^{\circ} \mathrm{C}$.

\subsection{Quality assurance and quality control}

The ${ }^{37} \mathrm{Cl}_{4}$-labeled 2,3,7,8-tetrachlorodibenzo-p-dioxin recoveries were $93-105 \%$, indicating that the sampling efficiency was satisfactory. The ${ }^{13} \mathrm{C}_{12}$-labeled PBDD/F internal standard recoveries were $24-115 \%$, and met the requirements for the trace analysis of dioxins and dioxin-like compounds in environmental samples. The 2,3,7,8-brominated PBDD/F congeners were identified using the isotope dilution method. Three quality control criteria were used when identifying each target compound: (a) the retention time was matched to the corresponding ${ }^{13} \mathrm{C}_{12}$-labeled standard; (b) the signal-to-noise ratio was higher than 3 ; and (c) the ratio between the areas of the quantification and identification ion peaks was within $\pm 15 \%$ of the theoretical value. One blank sample was included in each batch of samples analyzed. The 1,2,3,4,6,7,8heptabromodibenzofuran (HpBDF) and octabromodibenzofuran (OBDF) concentrations were a little higher than the detection limits but were less than $2 \%$ of the concentrations in the stack gas samples. The stack gas sample volumes were normalized to "dry standard conditions" of $273 \mathrm{~K}$ and $101.3 \mathrm{kPa}$, the units for which are labeled $\mathrm{Nm}^{3}$.

\section{Results and discussion}

\subsection{PBDD/F and PBDE emissions during the SAl processes}

The PBDD/F concentrations found in the stack gas samples from the four plants are shown in Table 1. The PBDD/F concentrations in the samples from the different plants varied widely, from 144 to $4573 \mathrm{pg} \mathrm{Nm}^{-3}$. The highest PBDD/F concentrations were found in the samples from Plant1, for which the mean concentration was $3578 \mathrm{pg} \mathrm{Nm}^{-3}$ (range 1937-4573 pg Nm${ }^{-3}$ ). The mean PBDD/F concentration in the samples from Plant2 was $1049 \mathrm{pg} \mathrm{Nm}^{-3}$ (range 729-1467 $\mathrm{pg} \mathrm{Nm}^{-3}$ ). The PBDD/F concentrations were much lower in the samples from Plant 3 than in the samples from Plant 1 and
Plant2, the mean being $272 \mathrm{pg} \mathrm{Nm}^{-3}$ and the range being 259-296 pg Nm${ }^{-3}$. The PBDD/F concentrations were lower in the samples from Plant4 than in the samples from the other plants, the mean being $171 \mathrm{pg} \mathrm{Nm}^{-3}$ and the range being 144-206 $\mathrm{pg} \mathrm{Nm}^{-3}$.

The results of previous studies in which PBDD/F concentrations were measured in stack gases emitted from SAl plants and other industrial thermal processes are summarized in Table 2 (Du et al., 2010; Wang et al., 2010a, 2010b; Drage et al., 2014; Li et al., 2015; Wang et al., 2015). Very few studies of PBDD/Fs unintentionally released from SAl plants have been performed, and, to the best of our knowledge, only one such study has been published (Du et al., 2010). The mean PBDD/F concentration in the stack gas samples collected in that study was $560 \mathrm{pg} \mathrm{Nm}^{-3}$. The PBDD/F concentrations we found $\left(144-4573 \mathrm{pg} \mathrm{Nm}^{-3}\right.$ ) were much higher than the concentrations that have previously been found in stack gases produced by municipal solid waste incinerators and converter steelmaking processes (Wang et al., 2010a, 2010b; Li et al., 2015) and were higher than or comparable to the concentrations that have previously been found in stack gases produced during iron ore sintering processes, secondary copper smelting processes, and electric arc furnace processes (Du et al., 2010; Wang et al., 2010b, 2015). These results show that SAl plants are important sources of PBDD/F emissions.

There are currently no internationally agreed toxic equivalency factors for PBDD/F congeners relative to 2,3,7,8-tetrachlorodibenzop-dioxin. It has been suggested by a number of researchers and by the Word Health Organization that PCDD/F toxic equivalency factors should be used for the PBDD/Fs (WHO, 1998; Wang et al., 2010a; Ren et al., 2011). The PCDD/F toxic equivalency factors shown in Table S2 were therefore used to calculate the PBDD/F TEQ in this study. The PBDD/F TEQ concentrations in the stack gas samples from the four SAl plants were $0.0039-0.053 \mathrm{ng}^{2} \mathrm{TEQ} \mathrm{Nm}^{-3}$ (see Table S3). The highest PBDD/F TEQ concentrations were found in the stack gas samples from Plant1, for which the mean was $0.043 \mathrm{ng}$ TEQ $\mathrm{Nm}^{-3}$ (range $0.024-0.053 \mathrm{ng}$ TEQ $\mathrm{Nm}^{-3}$ ). The mean PBDD/F TEQ concentration in the Plant2 stack gases was $0.030 \mathrm{ng} \mathrm{TEQ} \mathrm{Nm}^{-3}$ (range 0.015-0.042 ng TEQ Nm${ }^{-3}$ ). The PBDD/F TEQ concentrations in the Plant3 and Plant4 stack gases were 0.013-0.019 and 0.0039-0.0079 ng TEQ $\mathrm{Nm}^{-3}$, respectively. The concentrations in the stack gases from all four plants were below $0.1 \mathrm{ng}$ TEQ $\mathrm{Nm}^{-3}$, which is the regulatory limit for dioxin emissions from some industrial sources (Liu et al., 2013, 2015).

It is widely recognized that PBDEs are important precursors of PBDD/Fs formed during industrial thermal processes (Weber and Kuch, 2003; Olsman et al., 2007; Altarawneh and Dlugogorski, 2013; Sindiku et al., 2014). Altarawneh and Dlugogorski (2013) performed a detailed mechanistic and kinetic study of the formation of PBDD/Fs from PBDEs, and found that the loss of ortho $\mathrm{Br}$ or $\mathrm{H}$ atoms from a PBDE, followed by a ring-closure reaction, is the most accessible pathway for the production of PBDFs via modest reaction barriers. Weber and Kuch (2003) stated that PBDD/Fs can be formed from PBDEs via the simple intramolecular elimination of $\mathrm{HBr}$. In this study, the PBDE concentrations were also determined, and they are shown in Table S4. The PBDE concentrations in the samples from the four plants ranged from 7.8 to $102.1 \mathrm{ng} \mathrm{Nm}{ }^{-3}$. The dominant PBDE congener was BDE-209, and the next most dominant congeners were BDE-99 and BDE-47. The PBDE concentrations were much (about 5-244 times) higher than the PBDD/F concentrations in the stack gas samples. The PBDE emissions at different smelting stages in Plant1 and Plant2 followed similar patterns to the PBDD/F emissions. It has been suggested in several studies that BDE-209 could be transformed into OBDF or HpBDFs (Ren et al., 2011; Vetter et al., 2015). It can be seen from Fig. S1 that BDE-209 emissions at different smelting stages in Plant1 and Plant2 followed similar patterns to the OBDF and HpBDF emissions. The high 
Table 1

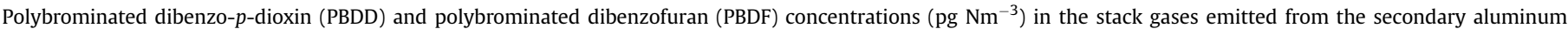
smelting plants.

\begin{tabular}{|c|c|c|c|c|c|}
\hline Plant & & $\sum$ PBDDs & $\sum$ PBDFs & Ratio $^{a}$ & $\sum \mathrm{PBDD} / \mathrm{Fs}$ \\
\hline \multirow[t]{3}{*}{ Plant1 } & $\mathrm{FF}^{\mathrm{b}}$ & 105 & 4468 & 0.02 & 4573 \\
\hline & $\mathrm{RE}^{\mathrm{c}}$ & 64 & 4156 & 0.02 & 4221 \\
\hline & $\mathrm{CA}^{\mathrm{d}}$ & 74 & 1863 & 0.04 & 1937 \\
\hline \multirow[t]{4}{*}{ Plant2 } & $\mathrm{FF} 1$ & 525 & 865 & 0.61 & 1390 \\
\hline & FF2 & 574 & 893 & 0.64 & 1467 \\
\hline & $\mathrm{RE}$ & 398 & 553 & 0.72 & 950 \\
\hline & CA & 331 & 398 & 0.83 & 729 \\
\hline \multirow[t]{4}{*}{ Plant3 } & Mix1 & 103 & 193 & 0.53 & 296 \\
\hline & Mix2 & 81 & 192 & 0.42 & 274 \\
\hline & Mix3 & 83 & 178 & 0.47 & 261 \\
\hline & Mix4 & 65 & 194 & 0.34 & 259 \\
\hline \multirow[t]{4}{*}{ Plant4 } & Mix1 & 46 & 160 & 0.29 & 206 \\
\hline & Mix2 & 44 & 130 & 0.34 & 173 \\
\hline & Mix3 & 45 & 120 & 0.38 & 164 \\
\hline & Mix4 & 39 & 104 & 0.38 & 144 \\
\hline
\end{tabular}

a Ratio calculated as $\sum 2,3,7,8-P B D D s / \sum 2,3,7,8-P B D F s$.

b FF, feeding-fusion.

c RE, refining.

d CA, casting.

Table 2

Polybrominated dibenzo-p-dioxin and dibenzofuran (PBDD/F) concentrations found in stack gases from different industrial thermal processes.

\begin{tabular}{|c|c|c|c|c|}
\hline \multirow{2}{*}{$\begin{array}{l}\text { Industrial thermal processes } \\
\text { Municipal solid waste incinerators }\end{array}$} & \multirow{2}{*}{$\frac{\text { Number of samples }}{7}$} & \multicolumn{2}{|c|}{ PBDD/F concentration $\left(\mathrm{pg} \mathrm{Nm}^{-3}\right)$} & \multirow{2}{*}{$\frac{\text { Reference }}{\text { (Wang et al., 2010a) }}$} \\
\hline & & $65-88$ & tetra- to octa- & \\
\hline Converter Steelmaking Processes & 15 & $36-183$ & tetra- to octa- & (Li et al., 2015) \\
\hline Electric arc furnaces & 6 & $20-2780$ & tetra- to octa- & (Wang et al., 2010b) \\
\hline Iron ore sintering process & 5 & $183-3010$ & tetra- to octa- & (Wang et al., 2010b) \\
\hline Iron ore sintering process & 15 & $370-710$ & tetra- to hexa- & (Drage et al., 2014) \\
\hline Secondary copper smelting process & 8 & $115-559$ & tetra- to octa- & (Wang et al., 2015) \\
\hline Secondary copper smelting process & 1 & 2500 & tetra- to hexa- & (Du et al., 2010) \\
\hline Secondary aluminum smelting & 1 & 560 & tetra- to hexa- & (Du et al., 2010) \\
\hline Secondary aluminum smelting & 15 & $144-4573$ & tetra- to octa- & This study \\
\hline
\end{tabular}

concentrations of PBDE congeners (including BDE-209) may therefore have provided abundant brominated precursors for the formation of PBDD/Fs, especially OBDF and HpBDFs, during the SAl processes.

\section{2. $P B D D / F$ emissions from different stages of the SAl processes}

There are three distinct stages in the SAl process, feeding-fusion (FF), refining, and casting. Raw materials are first added to the furnace and heated by burning fuel. When the raw material has almost melted, alloying agents (zinc, copper, magnesium, or silicon) are added to modify the strength and ductility of the final product. The refined liquid aluminum is poured into molds or casting machines to produce aluminum ingots. $\mathrm{PBDD} / \mathrm{Fs}$ may be formed and emitted during each smelting stage because of the incomplete combustion of organic and bromine-containing material (Sinkkonen et al., 2004). Different amounts and profiles of PBDD/Fs may be emitted at different stages of the smelting process. Plant1 and Plant2 each had only one furnace operating during the sampling period. This made it possible to examine the different amounts and profiles of PBDD/Fs emitted during the different smelting stages in these plants without interference from other furnaces sharing the same air pollution control devices. Separate stack gas samples were collected while the FF, refining, and casting processes were being performed in Plant1 and Plant2.

The PBDD/F concentrations in the samples from Plant 1 and Plant2 while the different smelting processes were being performed are shown in Fig. 1. The highest PBDD/F concentrations (4573 and $1467 \mathrm{pg} \mathrm{Nm}^{-3}$ in the Plant1 and Plant2 samples, respectively) were found during the FF process at both plants. The raw materials were melted in the FF process using heat supplied by burning fuel. The raw materials were added to the furnace in several batches, and the unsteady conditions that would have occurred each time raw material was added could have led to the incomplete combustion of fuel or organic impurities in the raw materials. It has previously been found that PBDD/Fs can easily form when an unsteady state occurs during an industrial thermal process (Weber and Kuch, 2003; D'Silva et al., 2004). The FF stage took 4-6 h in Plant1 and Plant2. The duration of the FF stage and the conditions under which it was performed make it unsurprising

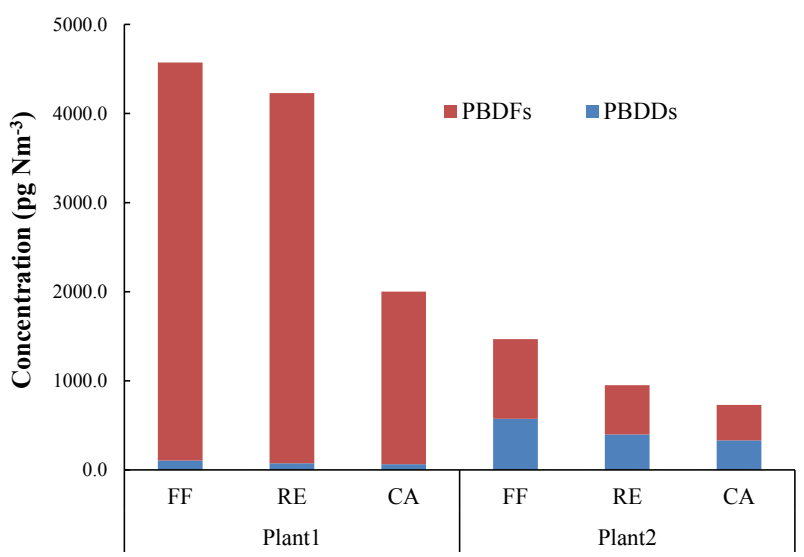

Fig. 1. Polybrominated dibenzo-p-dioxin (PBDD) and polybrominated dibenzofuran (PBDF) concentrations in stack gases produced during different stages of the smelting process in Plant1 and Plant2 ( $\mathrm{FF}=$ feeding-fusion, $\mathrm{RE}=$ refining, and $\mathrm{CA}=$ casting). 
that large amounts of PBDD/Fs were formed and emitted while the FF stage was performed. The PBDD/F concentrations were slightly lower in the samples collected during the refining stage (4221 and $950 \mathrm{pg} \mathrm{Nm}^{-3}$ for the Plant1 and Plant2 samples, respectively) than in the samples collected during the FF stage. Some organic impurities in the raw materials would still have been present in the respectively. Therefore, we attempted to determine whether PBDD/ F emissions were affected by the composition of the raw material used. To achieve this, we estimated PBDD/F emission factors for Plant1, Plant2, and Plant3 from the PBDD/F concentrations in the stack gas samples, the stack gas flow rates, and the aluminum production capacities using Equation (1).

$$
\begin{aligned}
\text { Emission factor }\left(\mathrm{ng} \mathrm{t}^{-1}\right)= & \left(\text { Concentration in stack gas }\left(\mathrm{ng} \mathrm{Nm}^{-3}\right) \times \operatorname{Stack} \text { gas flow rate }\left(\mathrm{Nm}^{3} \mathrm{~h}^{-1}\right)\right) \\
& / \text { Aluminum production capacity }\left(\mathrm{t} \mathrm{h}^{-1}\right)
\end{aligned}
$$

furnace during the refining stage because the furnace contents will have been insufficiently mixed for the organic material to have been completely removed during the FF stage. Alloying agents are added to the liquid layer of aluminum during the refining stage to modify the strength and ductility of the aluminum produced. PBDD/Fs may therefore be produced during the refining stage because of the presence of organic impurities and metal oxides. Almost all of the organic impurities in the raw material will have been removed in the FF and refining processes, so very little organic material will be present during the casting stage. The PBDD/F concentrations were lower in the stack gas samples collected during the casting stage (1937 and $729 \mathrm{pg} \mathrm{Nm}^{-3}$ in the Plant 1 and Plant2 samples, respectively) than in the samples collected during the FF and refining stages.

The results and information presented above lead us to suggest that variations in $\mathrm{PBDD} / \mathrm{F}$ emissions during SAl processes may be related to the different smelting stages. PBDD/F emissions during SAl were found to occur mainly during the FF stage. These results may be useful in the development of techniques for decreasing PBDD/F emissions during SAl processes.

\subsection{Influence of the raw material composition on $P B D D / F$ emissions}

The raw materials, smelting technique, and furnace capacity might influence emissions of unintentionally produced POPs during an industrial thermal process (Li et al., 2007; Ba et al., 2009; Wang et al., 2010b; Hu et al., 2014; Li et al., 2015; Wang et al., 2015). Identifying the effects of key factors on $\mathrm{PBDD} / \mathrm{F}$ emissions could allow steps to be taken to significantly decrease PBDD/F emissions from SAl plants. We therefore investigated the influences of the raw materials, smelting techniques, and furnace capacities used in the plants on the PBDD/F concentrations in the stack gas samples. No significant correlation was found between the furnace capacity and the PBDD/F concentration. The relationships between the $\mathrm{PBDD} / \mathrm{F}$ concentrations and the scrap pretreatments and raw material compositions that were used were assessed.

In our previous studies, we found that using raw materials with different compositions can cause different amounts and profiles of PCDD/Fs, PCBs, and PCNs to be emitted during secondary metal smelting processes (Hu et al., 2013b; Jiang et al., 2015). Few studies of the influences of different raw material compositions in metal smelting processes on PBDD/F emissions have been performed. Plant1, Plant2, and Plant3 all had bag filter air pollution control devices and used similar furnaces and raw material pretreatment techniques. The most obvious difference between the three plants was the raw material used. Dirty scrap aluminum contributed $100 \%$, $80 \%$, and $50 \%$ of the raw materials used in Plant1, Plant2, and Plant3,
The PBDD/F emission factors were in the range $14-180 \mu \mathrm{g} \mathrm{t}^{-1}$. The PBDD/F emission factors for Plant1, Plant2, and Plant3 are shown in Fig. 2A. It can be seen from Fig. 2A that Plant1, which used only dirty aluminum scrap as a raw material, had the highest PBDD/ $\mathrm{F}$ emission factor, $180 \mu \mathrm{g} \mathrm{t}^{-1}$. Dirty aluminum scrap typically contains relatively large amounts (18-20\% by weight) of organic residues, such as plastics, paints, and solvents (Kevorkjjan, 2010). Using raw materials with higher organic residue contents will lead to more PBDD/Fs being emitted during the smelting process. It is therefore not surprising that relatively large amounts of PBDD/Fs were found in the stack gas samples from Plant1. The PBDD/F

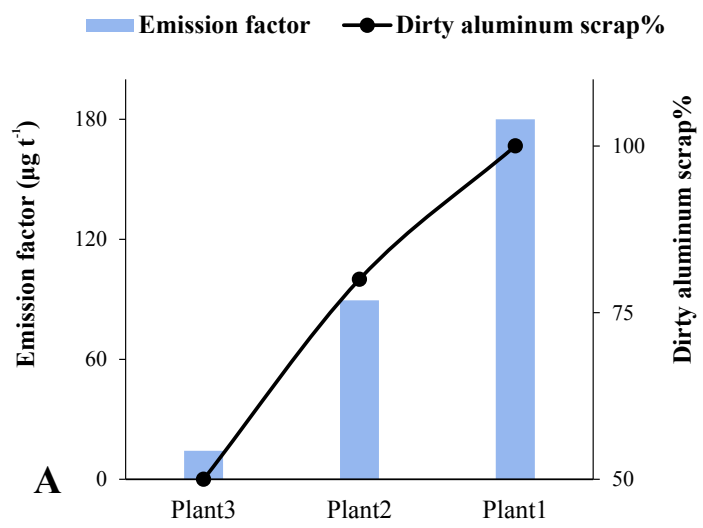

$\sum($ OBDFs+HpBDFs+OBDDs+HpBDDs $) \multimap-$ Dirty aluminum scrap $\%$

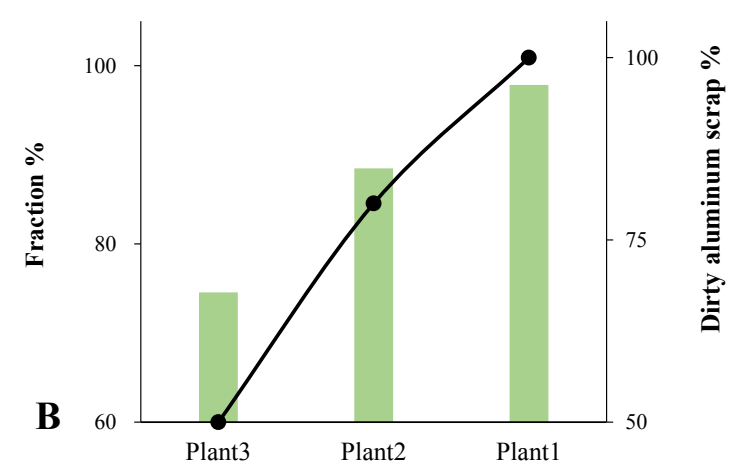

Fig. 2. Relationships between the dirty aluminum scrap contents of the raw materials used in Plant1, Plant2, and Plant3 and (A) the polybrominated dibenzo-p-dioxin and dibenzofuran (PBDD/F) emission factors and $(B)$ the sums of the octabromodibenzofuran (OBDF), 1,2,3,4,6,7,8-heptabromodibenzofuran (HpBDF), octabromodibenzo- $p$ dioxin (OBDD), and 1,2,3,4,6,7,8-heptabromodibenzo-p-dioxin (HpBDD) contributions to the total PBDD/F concentrations. 
emission factor for Plant2, which used $80 \%$ dirty aluminum scrap and $20 \%$ copper-clad aluminum wire as its raw material, was $86 \mu \mathrm{g} \mathrm{t}^{-1}$, and this was lower than the emission factor for Plant1. Plant3, which used 50\% dirty aluminum scrap and 50\% clean aluminum scrap as its raw material, had the lowest PBDD/F emission factor, $14 \mu \mathrm{g} \mathrm{t}^{-1}$. The PBDD/F emission factor increased as the dirty aluminum scrap content of the raw material increased. These results indicate that the composition of the raw material used in a SAl plant is one of the key factors influencing PBDD/F emissions from the plant. The composition of the raw material, especially the proportion of secondary materials (such as dirty aluminum scrap) with high organic impurity contents, should be given careful consideration when evaluating PBDD/F emissions from SAl plants.

\subsection{Effect of scrap pretreatment on decreasing PBDD/F emissions}

The scrap pretreatment process generally involves sorting, washing, depitching, crushing, and drying the scrap to remove contaminants and prepare the material for smelting. In the sorting process, aluminum is separated from other metals and nonmetallic materials such as plastics and paint. The scrap is then washed to remove dirt and oil, then the depitching process removes paint and other coatings from the surfaces of the aluminum. The scrap is crushed to break it into small pieces to improve the efficiency at which iron can later be removed using magnets. The aluminum scrap will still contain some organic contaminants, and these are removed by drying the scrap in rotary dryers.

All of the feed materials used in the plants we studied were precleaned, but different pretreatment techniques were used in the different plants. The feed materials used in Plant 4 were subjected to a series of standardized pretreatments that included manual and magnetic separation, washing, depitching, crushing, and tumble drying at about $400{ }^{\circ} \mathrm{C}$. The feed materials used in Plant1, Plant2, and Plant 3 were not effectively pretreated but were simply dried at a relatively low temperature, $150-200{ }^{\circ} \mathrm{C}$. Plant 4 and Plant 1 used only dirty aluminum scrap as the raw material. The mean PBDD/F concentration in the stack gas from Plant4, in which the raw materials were pretreated effectively, was $171 \mathrm{pg} \mathrm{Nm}^{-3}$, which was significantly (a factor of 20) lower than the mean concentration in the stack gas from Plant1 $\left(3577 \mathrm{pg} \mathrm{Nm}^{-3}\right.$ ), in which the raw materials were only dried at a low temperature. The PBDD/F concentrations were also markedly lower in the stack gas from Plant 4 than in the stack gas from Plant 2 and Plant 3 (the concentrations were 1049 and $272 \mathrm{pg} \mathrm{Nm}^{-3}$ in the samples from Plant2 and Plant3, respectively), which used raw materials containing 50-80\% dirty aluminum scrap that was not pretreated effectively. It has been shown that the incomplete combustion of organic impurities in raw materials leads to the unintentional production of POPs during a number of industrial thermal processes (Fiedler, 2007; Gullett et al., 2009; Li et al., 2015). Effective pretreatment of scrap metal can significantly decrease the organic impurity content of the raw material, meaning that smaller amounts of PBDD/Fs will be formed through the incomplete combustion of organic impurities during smelting. Our results clearly indicate that the effective pretreatment of scrap aluminum has an important role to play in decreasing PBDD/F emissions during SAl processes.

\subsection{Congener profiles of the PBDD/Fs in the stack gas samples}

The tetra- to octa-brominated PBDD/F homolog profiles, shown in Fig. S2, were evaluated to improve our understanding of the PBDD/F emissions from the SAl plants we studied. The hepta- and octa-brominated PBDD/Fs were the main homologs in the stack gas samples from all of the plants, together contributing $97-98 \%$,
$84-94 \%, 64-81 \%$, and $86-90 \%$ of the total PBDD/F concentrations in the samples from Plant1, Plant2, Plant3, and Plant4, respectively. It can be seen from Fig. S2 that the relative contributions of the tetrabrominated $\mathrm{PBDD} / \mathrm{F}$ homologs were higher in the Plant3 samples $(12-15 \%)$ than in the samples from Plant1 $(0.20-0.39 \%)$, Plant2 (0.70-3.7\%), and Plant4 (1.0-3.2\%). The PBDF concentrations were much higher than the PBDD concentrations in the stack gas samples, the PBDFs contributing 94-99\%, 55-97\%, 65-68\%, and $73-90 \%$, of the total PBDD/F concentrations in the stack gas samples from Plant1, Plant2, Plant3, and Plant4, respectively.

The PBDD/F congener profiles can help identify the PBDD/F formation mechanisms and sources. We selected thirteen 2,3,7,8substituted PBDD/F congeners to "fingerprint" the PBDD/Fs produced during SAl processes. The concentration of each $\mathrm{PBDD} / \mathrm{F}$ congener was normalized to the total 2,3,7,8-substituted PBDD/F concentration to allow the PBDD/F patterns to be compared effectively. The PBDD/F congener profiles in the stack gas samples from the SAl plants we studied are shown in Fig. 3. As is shown in Fig. 3, the more brominated PBDD/F congeners (OBDF, 1,2,3,4,6,7,8HpBDF, octabromodibenzo-p-dioxin (OBDD), and 1,2,3,4,6,7,8heptabromodibenzo-p-dioxin (HpBDD)) were the dominant congeners in the samples from all of the plants. The contributions of the PBDD and PBDF congeners to the total 2,3,7,8-substituted $\mathrm{PBDD} / \mathrm{F}$ concentrations in the Plant2 samples increased as the degree of bromination increased, and OBDD and OBDF contributed more than the other congeners to the total 2,3,7,8-substituted $\mathrm{PBDD} / \mathrm{F}$ concentrations. The Plant 4 samples had similar tetra- to octa-brominated PBDD and tetra- to hexa-brominated PBDF congener patterns to the Plant 2 samples, but OBDF contributed significantly less than $1,2,3,4,6,7,8-\mathrm{HpBDF}$ to the total PBDD/F concentrations in the Plant4 samples than in the Plant2 samples. The Plant1 samples did not have the same congener pattern, the hepta-to octa-brominated PBDF congeners contributing far more than the tetra-to hexa-brominated PBDD/F congeners to the total 2,3,7,8-substituted PBDD/F concentrations. The most abundant congener in the Plant3 samples was OBDF, and the next most abundant were 1,2,3,4,6,7,8-HpBDF, OBDD, and 1,2,3,4,6,7,8HpBDD.

The $\mathrm{PBDD} / \mathrm{F}$ congener profiles in samples from waste incinerators, secondary copper production plants, iron ore sintering plants, and electric arc furnaces (used to produce steel) have previously been found to be dominated by the more brominated PBDFs, particularly OBDF and 1,2,3,4,6,7,8-HpBDF (Wang et al., 2010b; Wyrzykowska-Ceradini et al., 2011; Li et al., 2015; Wang et al., 2015). The PBDD/F congener profiles in our SAl samples were similar to the profiles that have been found in samples from waste incinerators, secondary copper production plants, iron ore sintering plants, and electric arc furnaces, suggesting similar PBDD/F formation mechanisms occur in the processes performed in each of these types of plant.

As described above, we concluded that using raw materials with different compositions caused there to be different PBDD/F concentrations in stack gases produced by the SAl plants. The more brominated PBDD/F congeners were the dominant contributors to the total 2,3,7,8-substituted PBDD/F concentrations in the stack gas samples. We evaluated the influence of the raw materials used on the $\mathrm{PBDD} / \mathrm{F}$ congener patterns by estimating the contributions of the more brominated PBDD/F congeners (OBDF, 1,2,3,4,6,7,8HpBDF, OBDD, and $1,2,3,4,6,7,8-H p B D D)$ to the total $2,3,7,8-$ substituted PBDD/F concentrations in the samples from Plant1, Plant2, and Plant3. The relationship between the sums of the contributions of OBDF, 1,2,3,4,6,7,8-HpBDF, OBDD, and 1,2,3,4,6,7,8HpBDD to the total 2,3,7,8-substituted PBDD/F concentrations and the dirty aluminum scrap contents of the raw materials for Plant1, Plant2, and Plant3 is clearly shown in Fig. 2B. 

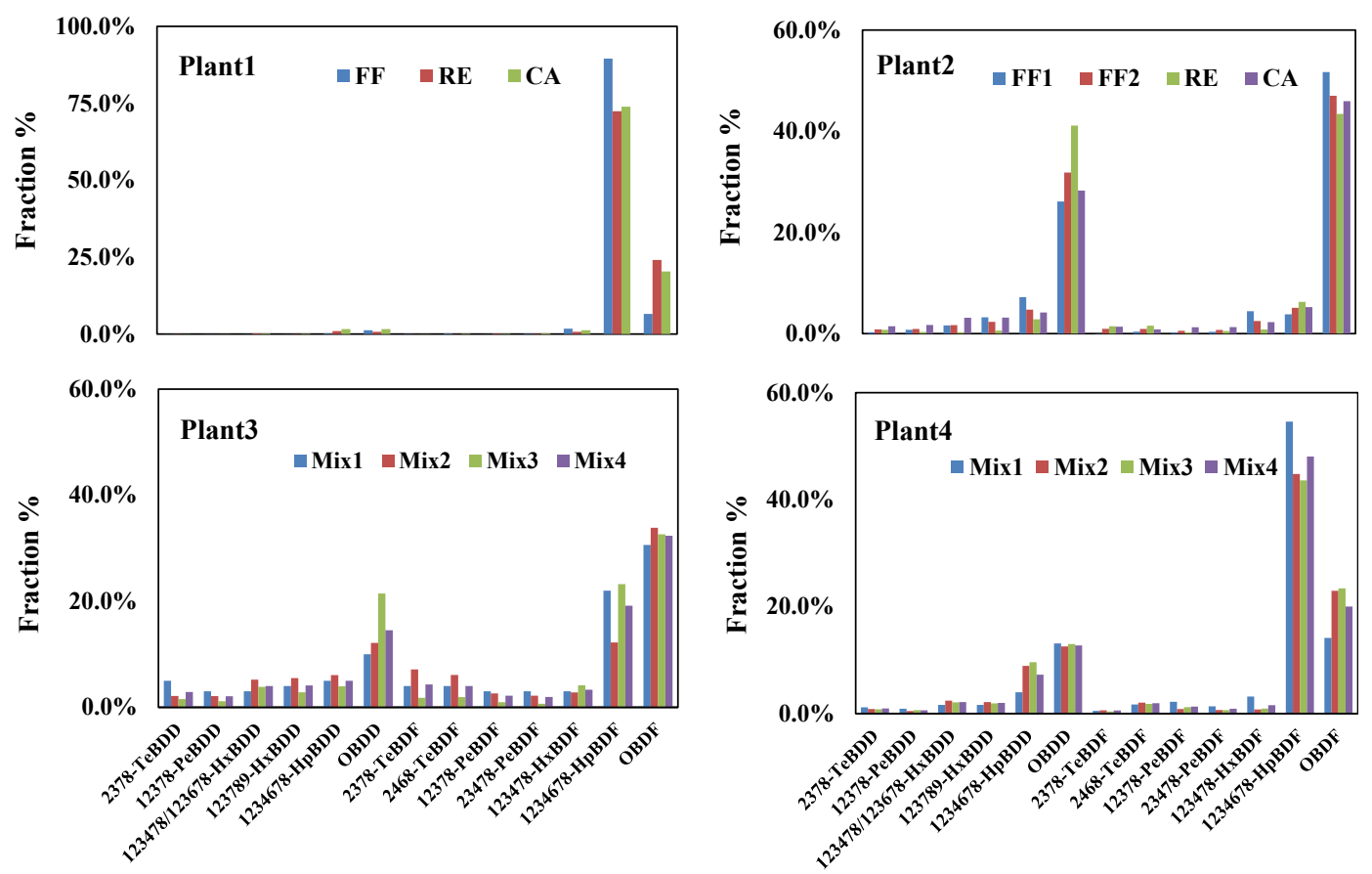

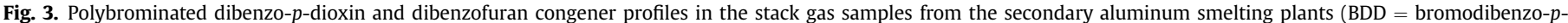
dioxin, $\mathrm{BDF}=$ bromodibenzofuran, $\mathrm{Te}=$ tetra, $\mathrm{Pe}=$ penta, $\mathrm{Hx}=$ hexa, $\mathrm{Hp}=$ hepta, $\mathrm{O}=$ octa).

The sum of the OBDF, 1,2,3,4,6,7,8-HpBDF, OBDD, and $1,2,3,4,6,7,8-\mathrm{HpBDD}$ contributions to the total 2,3,7,8-substituted PBDD/F concentration was $98 \%$ for Plant1, which used only dirty aluminum scrap as its raw material. The sum of the OBDF, 1,2,3,4,6,7,8-HpBDF, OBDD, and 1,2,3,4,6,7,8-HpBDD contributions to the total 2,3,7,8-substituted PBDD/F concentration was lower, at $89 \%$, for Plant2, which used $80 \%$ dirty aluminum scrap and $20 \%$ copper-clad aluminum wire as its raw materials. The sum of the OBDF, 1,2,3,4,6,7,8-HpBDF, OBDD, and 1,2,3,4,6,7,8-HpBDD contributions to the total 2,3,7,8-substituted PBDD/F concentration was lower still, at 75\%, for Plant3, which used 50\% dirty aluminum scrap and $50 \%$ clean aluminum scrap as its raw materials. We concluded that the contribution of the more brominated PBDD/F congeners (the hepta- and octa-brominated PBDD/Fs) increased as the dirty aluminum scrap content of the raw material increased at the plants we studied. It is therefore clear that using raw materials with different compositions can affect both the amounts of PBDD/Fs emitted and the congener patterns of the PBDD/Fs emitted during SAl processes.

\section{Conclusions}

We measured PBDD/F emissions and the PBDD/F congener patterns in stack gases produced in four typical SAl plants in China. High PBDD/F concentrations were found in the stack gas samples, but the $\mathrm{PBDD} / \mathrm{F}$ concentrations and congener profiles varied widely. The composition of the raw materials used in a SAl plant was found to be a key factor influencing the amounts of PBDD/Fs emitted and the $\mathrm{PBDD} / \mathrm{F}$ congener profiles. $\mathrm{PBDD} / \mathrm{F}$ emission factors were derived for the plants using different proportions of dirty aluminum scrap in their raw material feeds. Larger amounts of $\mathrm{PBDD} / \mathrm{Fs}$ were found to be emitted during the FF stage than in the other stages. We found that effectively pretreating aluminum scrap can significantly decrease the amounts of PBDD/Fs emitted. Different PBDD/F congener profiles were found in the samples from the SAl plants using raw materials with different compositions.

\section{Acknowledgments}

We gratefully acknowledge support from the National 973 Program (2015CB453100), the Strategic Priority Research Program of the Chinese Academy of Sciences (XDB14020102), and the National Natural Science Foundation of China (21477147).

\section{Appendix A. Supplementary data}

Supplementary data related to this article can be found at http:// dx.doi.org/10.1016/j.chemosphere.2015.11.109.

Supplementary data associated with this article can be found in the online version, at http://www.elsevier.com.

\section{References}

Altarawneh, M., Dlugogorski, B.Z., 2013. A mechanistic and kinetic study on the formation of PBDD/Fs from PBDEs. Environ. Sci. Technol. 47, 5118-5127.

Altarawneh, M., Dlugogorski, B.Z., Kennedy, E.M., Mackie, J.C., 2009. Mechanisms for formation, chlorination, dechlorination and destruction of polychlorinated dibenzo-p-dioxins and dibenzofurans (PCDD/Fs). Prog. Energy Combust. Sci. 35 245-274.

Ba, T., Zheng, M., Zhang, B., Liu, W., Su, G., Liu, G., Xiao, K., 2010. Estimation and congener-specific characterization of polychlorinated naphthalene emissions from secondary nonferrous metallurgical facilities in China. Environ. Sci. Technol. 44, 2441-2446.

Ba, T., Zheng, M., Zhang, B., Liu, W., Xiao, K., Zhang, L., 2009. Estimation and characterization of PCDD/Fs and dioxin-like PCBs from secondary copper and aluminum metallurgies in China. Chemosphere 75, 1173-1178.

Behnisch, P.A., Hosoe, K., Sakai, S.-i., 2003. Brominated dioxin-like compounds: in vitro assessment in comparison to classical dioxin-like compounds and other polyaromatic compounds. Environ. Int. 29, 861-877.

Birnbaum, L.S., Staskal, D.F., Diliberto, J.J., 2003. Health effects of polybrominated dibenzo-p-dioxins (PBDDs) and dibenzofurans (PBDFs). Environ. Int. 29, $855-860$.

Chang, S.-S., Lee, W.-J., Wang, L.-C., Chang-Chien, G.-P., Wu, C.-Y., 2013. Energy recovery and emissions of PBDD/Fs and PBDEs from co-combustion of woodchip and wastewater sludge in an industrial boiler. Environ. Sci. Technol. 47 $12600-12606$.

Chen, S.-J., Lee, W.-S., Chang-Chien, G.-P., Wang, L.-C., Lee, W.-J., Kao, J.-H., Hu, M.-T. 2004. Characterizing polychlorinated dibenzo-p-dioxins and dibenzofurans in the surrounding environment and workplace of a secondary aluminum smelter 
Atoms. Environ. 38, 3729-3732.

Chen, W.-Q., Shi, L., 2012. Analysis of aluminum stocks and flows in mainland China from 1950 to 2009: exploring the dynamics driving the rapid increase in China's aluminum production. Resources. Resour. Conserv. Recycl. Resour. 65, 18-28.

D'Silva, K., Fernandes, A., Rose, M., 2004. Brominated organic micropollutants-igniting the flame retardant issue. Crit. Rev. Environ. Sci. Technol. 34, 141-207.

Drage, D.S., Aries, E., Harrad, S., 2014. Studies into the formation of PBDEs and PBDD/Fs in the iron ore sintering process. Sci. Total Environ. 485-486, 497-507.

Du, B., Zheng, M., Tian, H., Liu, A., Huang, Y., Li, L., Ba, T., Li, N., Ren, Y., Li, Y., Dong, S. $\mathrm{Su}, \mathrm{G} ., 2010$. Occurrence and characteristics of polybrominated dibenzo-pdioxins and dibenzofurans in stack gas emissions from industrial therma processes. Chemosphere 80, 1227-1233.

Duan, H., Li, J., Liu, Y., Yamazaki, N., Jiang, W., 2011. Characterization and inventory of PCDD/Fs and PBDD/Fs emissions from the incineration of waste printed circuit Board. Environ. Sci. Technol. 45, 6322-6328.

Fiedler, H., 2007. National PCDD/PCDF release inventories under the Stockholm convention on persistent organic pollutants. Chemosphere 67, S96-S108.

Fujimori, T., Takaoka, M., Takeda, N., 2009. Influence of $\mathrm{Cu}, \mathrm{Fe}, \mathrm{Pb}$, and $\mathrm{Zn}$ chlorides and oxides on formation of chlorinated aromatic compounds in MSWI fly ash. Environ. Sci. Technol. 43, 8053-8059.

Fujimori, T. Tanino, Y., Takaoka, M., 2013. Coexistence of $\mathrm{Cu}, \mathrm{Fe}, \mathrm{Pb}$, and $\mathrm{Zn}$ oxides and chlorides as a determinant of chlorinated aromatics generation in munic ipal solid waste incinerator fly ash. Environ. Sci. Technol. 48, 85-92.

Grochowalski, A., Lassen, C., Holtzer, M., Sadowski, M., Hudyma, T., 2007. Determination of PCDDs, PCDFs, PCBs and HCB emissions from the metallurgica sector in Poland. Environ. Sci. Pollut. Res. Int. 14, 326-332.

Gullett, B.K., Wyrzykowska, B., Grandesso, E., Touati, A., Tabor, D.G., Ochoa, G.S. 2009. PCDD/F, PBDD/F, and PBDE emissions from open burning of a residentia waste dump. Environ. Sci. Technol. 44, 394-399.

Haglund, P., Malmvärn, A., Bergek, S., Bignert, A., Kautsky, L., Nakano, T., Wiberg, K. Asplund, L., 2007. Brominated dibenzo-p-dioxins: a new class of marine toxins? Environ. Sci. Technol. 41, 3069-3074.

Hu, J., Zheng, M., Liu, W., Li, C., Nie, Z., Liu, G., Xiao, K., Dong, S., 2013a. Occupationa exposure to polychlorinated dibenzo-p-dioxins and dibenzofurans, dioxin-like polychlorinated biphenyls, and polychlorinated naphthalenes in workplaces of secondary nonferrous metallurgical facilities in China. Environ. Sci. Technol. 47, $7773-7779$

Hu, J., Zheng, M., Liu, W., Nie, Z., Li, C., Liu, G., Xiao, K., 2014. Characterization of polychlorinated dibenzo-p-dioxins and dibenzofurans, dioxin-like polychlorinated biphenyls, and polychlorinated naphthalenes in the environment surrounding secondary copper and aluminum metallurgical facilities in China. Environ. Pollut. 193, 6-12.

Hu, J., Zheng, M., Nie, Z., Liu, W., Liu, G., Zhang, B., Xiao, K., 2013b. Polychlorinated dibenzo-p-dioxin and dibenzofuran and polychlorinated biphenyl emissions from different smelting stages in secondary copper metallurgy. Chemosphere 90, 89-94.

Jiang, X., Liu, G., Wang, M., Liu, W., Tang, C., Li, L., Zheng, M., 2015. Case study of polychlorinated naphthalene emissions and factors influencing emission variations in secondary aluminum production. J. Hazard. Mater 286, 545-552.

Kevorkjjan, V., 2010. The recycling of standard quality wrought aluminum alloys from low-grade contaminated scrap. JOM 62, 37-42.

Lee, C.-C., Shih, T.-S., Chen, H.-L., 2009. Distribution of air and serum PCDD/F levels of electric arc furnaces and secondary aluminum and copper smelters. J. Hazard. Mater 172, 1351-1356

Lee, W.-S., Chang-Chien, G.-P., Wang, L.-C., Lee, W.-J., Wu, K.-Y., Tsai, P.-J., 2005 Emissions of polychlorinated dibenzo-p-dioxins and dibenzofurans from stack gases of electric arc furnaces and secondary aluminum smelters. J. Air. Waste Manag. 55, 219-226.

Li, H.-W., Lee, W.-J., Huang, K.-L., Chang-Chien, G.-P., 2007. Effect of raw materials on emissions of polychlorinated dibenzo-p-dioxins and dibenzofurans from the stack flue gases of secondary aluminum smelters. J. Hazard. Mater 147, $776-784$.

Li, H., Feng, J., Sheng, G., Lü, S., Fu, J., Peng, P.a, Man, R., 2008. The PCDD/F and PBDD/ F pollution in the ambient atmosphere of Shanghai, China. Chemosphere 70 576-583.

Li, S., Liu, W., Liu, G., Wang, M., Li, C., Zheng, M., 2015. Atmospheric emission of polybrominated dibenzo-p-dioxins and dibenzofurans from converter steelmaking processes. Aerosol Air Qual. Res. 15, 1118-1124.
Liu, G., Zhan, J., Zheng, M., Li, L., Li, C., Jiang, X., Wang, M., Zhao, Y., Jin, R., 2015. Field pilot study on emissions, formations and distributions of PCDD/Fs from cement kiln co-processing fly ash from municipal solid waste incinerations. J. Hazard. Mater 299, 471-478.

Liu, G., Zheng, M., Jiang, G., Cai, Z., Wu, Y., 2013. Dioxin analysis in China. Trac Trends Anal. Chem. Trac 46, 178-188.

Liu, G.R., Zheng, M.H., Liu, W.B., Wang, C.Z., Zhang, B., Gao, L.R., Su, G.J., Xiao, K., Lv, P., 2009. Atmospheric emission of PCDD/Fs, PCBs, hexachlorobenzene, and pentachlorobenzene from the coking industry. Environ. Sci. Technol. 43, 9196-9201.

Liu, G.R., Zheng, M.H., Lv, P., Liu, W.B., Wang, C.Z., Zhang, B., Xiao, K., 2010. Estimation and characterization of polychlorinated naphthalene emission from coking industries. Environ. Sci. Technol. 44, 8156-8161.

Lo, K., Wang, M.Y., 2013. Energy conservation in China's Twelfth Five-Year Plan period: continuation or paradigm shift? Renew. Sustain. Energy Rev. 18, 499-507.

Olsman, H., Engwall, M., Kammann, U., Klempt, M., Otte, J., van Bavel, B., Hollert, H., 2007. Relative differences in aryl hydrocarbon receptor-mediated response for 18 polybrominated and mixed halogenated dibenzo-P-dioxins and -furans in cell lines from four different species. Environ. Toxicol. Chem. 26, 2448-2454.

Ortuño, N., Conesa, J.A., Moltó, J., Font, R., 2014. De Novo synthesis of brominated dioxins and furans. Environ. Sci. Technol. 48, 7959-7965.

Ren, M., Peng, P.A., Cai, Y., Chen, D.Y., Zhou, L., Chen, P., Hu, J.F., 2011. PBDD/F impurities in some commercial deca-BDE. Environ. Pollut. 159, 1375-1380.

Ryu, J.-Y., Mulholland, J.A., Chu, B., 2003. Chlorination of dibenzofuran and dibenzop-dioxin vapor by copper (II) chloride. Chemosphere 51, 1031-1039.

Sakai, S.-i., Watanabe, J., Honda, Y., Takatsuki, H., Aoki, I., Futamatsu, M., Shiozaki, K. 2001. Combustion of brominated flame retardants and behavior of its byproducts. Chemosphere 42, 519-531.

Samara, F. Gullett, B.K., Harrison, R.O., Chu, A., Clark, G.C., 2009. Determination of relative assay response factors for toxic chlorinated and brominated dioxins/ furans using an enzyme immunoassay (EIA) and a chemically-activated luciferase gene expression cell bioassay (CALUX). Environ. Int. 35, 588-593.

Sindiku, O, Babayemi, J. Osibanjo, O, Schlummer, M. Schluep, M. Watson, A. Weber, R., 2014. Polybrominated diphenyl ethers listed as Stockholm Convention POPs, other brominated flame retardants and heavy metals in e-waste polymers in Nigeria. Environ. Sci. Pollut. Res. 1-13.

Sinkkonen, S., Paasivirta, J., Lahtiperä, M., Vattulainen, A., 2004. Screening of halogenated aromatic compounds in some raw material lots for an aluminium recycling plant. Environ. Int. 30, 363-366.

Vetter, W., Bendig, P., Blumenstein, M., Hagele, F., Behnisch, P.A., Brouwer, A., 2015. Formation of polybrominated dibenzofurans (PBDFs) after heating of a salmon sample spiked with decabromodiphenyl ether (BDE-209). Environ. Sci. Pollut. Res. 22, 14530-14536.

Wang, L.-C., Hsi, H.-C., Wang, Y.-F., Lin, S.-L., Chang-Chien, G.-P., 2010a. Distribution of polybrominated diphenyl ethers (PBDEs) and polybrominated dibenzo-pdioxins and dibenzofurans (PBDD/Fs) in municipal solid waste incinerators. Environ. Pollut. 158, 1595-1602.

Wang, L.-C., Wang, Y.-F., Hsi, H.-C., Chang-Chien, G.-P., 2010b. Characterizing the emissions of polybrominated diphenyl ethers (PBDEs) and polybrominated dibenzo-p-dioxins and dibenzofurans (PBDD/Fs) from metallurgical processes. Environ. Sci. Technol. 44, 1240-1246.

Wang, M., Liu, G., Jiang, X., Liu, W., Li, L., Li, S., Zheng, M., Zhan, J., 2015. Brominated dioxin and furan stack gas emissions during different stages of the secondary copper smelting process. Atmos. Pollut. Res, 6, 464-468.

Weber, P., Dinjus, E., Stieglitz, L., 2001. The role of copper(II) chloride in the formation of organic chlorine in fly ash. Chemosphere 42, 579-582.

Weber, R., Kuch, B., 2003. Relevance of BFRs and thermal conditions on the formation pathways of brominated and brominated-chlorinated dibenzodioxins and dibenzofurans. Environ. Int. 29, 699-710.

WHO, 1998. Environmental Health Criteria 205, Polybrominated Dibenzo-p-dioxins and Dibenzofurans (Geneva, Switzerland).

Wyrzykowska-Ceradini, B., Gullett, B.K., Tabor, D., Touati, A., 2011. PBDDs/Fs and PCDDs/Fs in the raw and clean flue gas during steady state and transient operation of a municipal waste combustor. Environ. Sci. Technol. 45, $5853-5860$

Zacs, D., Rjabova, J., Bartkevics, V., 2013. Occurrence of brominated persistent organic pollutants (PBDD/DFs, PXDD/DFs, and PBDEs) in Baltic Wild Salmon (Salmo salar) and correlation with PCDD/DFs and PCBs. Environ. Sci. Technol. 47, 9478-9486. 